\title{
Some ethical-religious views of Nikolai \\ O. Lossky and Eugene V. Spektorsky \\ (searching for thought parallels)
}

\section{Niektoré eticko-náboženské názory Nikolaja O. Losského a Jevgenija V. Spektorského (hladaní myšlienkových paralel)}

Zlatica Plašienková - Oksana Slobodian

\begin{abstract}
Two famous Russian thinkers Nikolai O. Lossky (1870-1965) and E. Vasilievich Spektorsky (1875-1951) had a lot in common: both were talented intellectuals, lecturers and authors of many works on philosophy, history of philosophy, culture, politics and literature; both had to leave Russia and settle down abroad, and continue academic and creative activities in foreign environments. All these factors contributed to their friendly and intellectual communication which we want to pay attention to in this article.

The purpose of the article is to demonstrate similarities in how Lossky and Spektorsky formulated and addressed ethical issues on the grounding of Christianity and Christianbased philosophy. Thus, we have chosen several aspects of their ethical systems which are crucial for understanding the way of their moral thinking and which are representative in terms of comparison of these two authors: general philosophical positions, grounding ethics in Christianity, absolute basis of ethics and the way it can be cognized, human freedom, motives and goals of moral behavior, and moral evolution and the perspectives of humanity.
\end{abstract}

\section{Keywords}

N. O. Lossky, E. V. Spektorsky, religious philosophy, ethics of love, absolute good, human action, moral evolution

\section{Abstrakt}

Dvaja významní ruskí myslitelia Nikolaj O. Losskij (1870-1965) a Eugen V. Spektorskij 
(1875-1951) mali mnoho spoločného: obaja boli talentovaní intelektuáli, profesori a autori mnohých prác z filozofie, dejín filozofie, kultúry, politiky a literatúry; obaja museli opustit' Rusko, usadit' sa v zahraničí a pokračovat' v akademickej a vedeckej činnosti v cudzom prostredí. Všetky tieto faktory prispeli k ich priatel'skej a intelektuálnej komunikácii.

Ciel'om tohto príspevku je poukázat' na niektoré myšlienkové podobnosti, ktoré u nich nachádzame v oblasti formulovania a riešenia etických otázok. Ich základom bolo u obidvoch autorov krestáanské náboženstvo a krestáanská filozofia. Sústredili sme sa na niekol'ko významných aspektov ich etických koncepcií, ktoré sú rozhodujúce pre pochopenie ich myslenia a reprezentatívne z hl'adiska komparácie týchto dvoch autorov. Ide o všeobecnú filozofickú pozíciu, ukotvenie etiky v krestanstve, absolútny základ etiky a spôsob jeho poznania, problém l'udskej slobody, motívov a ciel'ov morálneho konania, morálnu evolúciu a perspektívy l'udstva.

\section{Kl'účové slová}

N. O. Losskij, E. V. Spektorskij, náboženská filozofia, etika lásky, absolútne dobro, l'udské konanie, morálna evolúcia

What could be found in common between a prominent Russian philosopher N. O. Lossky (1870-1965) and the last elected rector of the Saint Volodymyr Royal University in Kyiv E. V. Spektorsky (1875-1951)? Having looked at their biographies, one can discover many similarities. They were born almost at the same time, both were graduates of the best educational institutions in Russian Empire, both achieved high professional level in academic career, both wrote numerous works on philosophy, history of philosophy, culture and literature. Moreover, both Lossky and Spektorsky belonged to Russian anti-Bolshevik émigrés who were forced to leave the country in 1920's and continued their scientific and lecturing activities outside their motherland. Both died and were buried abroad.

Besides having similarities in their biographies, Lossky and Spektorsky were close intellectually, and this fact enabled their communication which remains a challenge for contemporary researches. This article aims at even more complicated task-enlightening parallels in their ethical-religious views.

In order to understand the connection between Lossky and Spektorsky we should start with the period of emigration which encouraged their communication. ${ }^{1}$

1 After 1989 the representatives of Russian interwar émigrés in Czechoslovakia and their works became an issue for many scientific investigations which were free of ideological influence. Among the most interesting publications regarding formation and exile of Rus- 
In 1922 Lossky together with many other intellectuals on well-known "philosopher's ship" (also "philosopher's steamboat") left Russia with his family and via Szczecin and Berlin arrived in Prague. Here he spent almost 20 years of his life, lecturing at Russian University, ${ }^{2}$ and being a guest professor in Brno, London, Paris, Geneva, Basel, Belgrade, Sofia, Naples, Warsaw, and other cities. After the disintegration of Czechoslovakia during a Nazi occupation of Bohemia and Moravia when universities were closed in 1941 Lossky was invited to lecture at Slovak University ${ }^{3}$ in Bratislava by the Slovak president Jozef Tiso. Here at the Department of philosophy he worked for three years (1942-1945). In 1945 he moved to his sons to Paris, and in 1947 as a professor of philosophy he was invited to lecture at Saint Vladimir's Orthodox Theological Academy to New York. He was also invited as a guest lecturer to other universities in the USA and Canada.

Spektorsky's path in emigration was very similar. After the Bolsheviks established themselves in Kyiv in 1920, he left to the Kingdom of Serbs, Croats and Slovenes where he worked as a professor at the Belgrade university. In 1924-1928 he lectured at the Law Faculty of Russian University in Prague and became its dean in 1927. From Prague he returned to Belgrade and then moved to Ljubljana where he lectured at the Ljubljana university in 1930-1945. From 1947 and to the end of his life on March 3, 1951 Spektorsky lived in the USA and, like Lossky, lectured at Saint Vladimir's Orthodox Theological Academy, and Columbia University.

In addition, both Lossky and Spektorsky belonged to the same intellectual circle and after Spektorsky left Prague they kept in touch, as we found out from Lossky's letters ${ }^{4}$ to Spektorsky dated 1928-1940 (from Prague to Ljubljana), which are currently being kept in Spektorsky's personal fond in the Archives of the Republic of Slovenia (Arhiv Republike Slovenije, SI AS 1901).

sian and Ukrainian émigrés we can mention a collected volume edited by L. Běloševská (see BĚLOŠEVSKÁ, Ljubov. Duchovni proudy ruské a ukrajinské emigrace v Československé republice (1919-1939). Praha: Slovanský ústav AV ČR 1999), or another book Дом в изгнании. Очерки о русской эмиграчии в Чехословакии 1918-1945. Praha: RT+RS Servis 2008).

2 He lectured in logic at the Law faculty and philosophical disciplines at the Historicalphilological faculty of the Russian University.

3 The name of the Comenius University in Bratislava in 1939-1954.

4 For instance, in letter from Prague to Ljubljana (August 4, 1939) Lossky promises to send Spektorsky his book Чувственная, интеллектуальная и мистическая интуииия [Sensual, intellectual and mystical intuition] and explains basic principles of his doctrine: what is idealrealism, the nature of real and ideal being, how ideal being correlates with real one and how the process of cognition happens. 
A few more times Lossky mentioned Spektorsky in his Воспоминания. Жизнь и философский путь [Memoirs: Life and Philosophical Path] ${ }^{5}$ and in his fundamental work История русской философии [History of Russian Philosophy]. ${ }^{6}$

For instance, when Lossky writes about his participation in the Congress of Russian academics in Belgrade in 1928, he recalls that "I had lively and pleasant philosophical conversation with Eugene Vasilievich Spektorsky..."7 Later describing history of foundation of Saint Vladimir's Orthodox Theological Academy in the USA Lossky remarks that he was invited there as a professor of philosophy and among other professors who came to lecture, he mentions Spektorsky who had arrived from Italy. ${ }^{8}$ Another fragment ${ }^{9}$ from Lossky's memoirs concerns his $80^{\text {th }}$ anniversary on December 6, 1950, the celebration of which was prepared by Spektorsky. Lossky did not attend it, though, as he was in Los Angeles with his son at that moment. A few months later in California Lossky found out about his colleague's death.

Spektorsky dedicated to Lossky an article ${ }^{10}$ published in Записки русккой академической группы в США [Russian Academic Group in the US] entitled Значение философии Н. О. Лосского [Significance of Lossky's philosophy] (in 1976, after they both died).

To return to История русской философии [History of Russian Philosophy] by Lossky it is essential to point out an interesting detail. Information about Spektorsky is a part of the chapter about philosophers-lawyers (next to a prominent Russian specialist in law Pavel Novgorodtsev), which is quite logical as Spektorsky was a Doctor of Law (1917, Moscow University) and during all his life he lectured in history, theory and philosophy of law. Nevertheless, Lossky reveals religious-philosophical aspect of Spektorsky's investigations when he remarks:

In his book Христианство и культура [Christianity and Culture] Spektorsky convincingly demonstrated considerable significance of Christianity for all the

5 ЛОССКИЙ, Н. О. Воспоминания..., р. 334.

6 ЛОССКИЙ, Н. О. История русской философии..., pp. 10, 286, 387, 388.

7 ЛОССКИЙ, Н. О. Воспоминания..., р. 246.

8 Ibidem, p. 296.

$9 \quad$ Ibidem, p. 301.

10 СПЕКТОРСКИЙ, Е. В. Значение философии Н. О. Лосского..., pp. 127-132. 
spheres of spiritual, social and even material culture-for philosophy, science and art, for development of an idea of personality, justice, state etc. ${ }^{11}$

In other parts of the book Lossky mentions Spektorsky among "philosophers-theologists" 12 and "religious philosophers"13. Thus, Lossky truly appreciated this aspect of Spektorsky's legacy; apparently, he found a lot of similar between Spektorsky's and his own way of reasoning over ethical problems.

Consequently, the purpose of this article is to reveal considerable similarities in the way how Lossky and Spektorsky developed their views on ethics and religion. Despite the fact that they were interested in different fields of philosophy and science (Spektorsky mainly concentrated on the history of ideas, ${ }^{14}$ and did not create such a full and coherent philosophical system as Lossky did), the Christian basis of ethics provided very similar way of argumentation, and they arrived at quite similar conclusions regarding human freedom, absolute basis for ethics and the way of its cognition, nature and goals of moral acting and moral evolution. All these issues are going to be discussed in further parts of the article.

\section{A philosophical position: Christianity as a basis of ethics}

It is a well-known fact that Lossky's philosophical system has a so-called universal character. It consists of ontology, noetics, logic, ethics, axiology, aesthetics and theodicy. Lossky's starting philosophical position is both the noetic position of intuitive realism and metaphysical personalism, which is also called the concrete, organic ideal-realism. His statement, which he called by this name, lets him belong to the people of "common sense" according to him, since it allows him to avoid conflicts among monism, dualism and pluralism, or between materialistic and idealistic extremes and to present the place of "equal" position of ideal and material sphere of being.

By the interconnectedness of these two spheres of being on the ethical ground Lossky wants to abolish the one-sided metaphysical moralism, but

11 ЛОССКИЙ, Н. О. История русской философии..., р. 387.

12 Ibidem, p. 10.

13 Ibidem, p. 286.

14 See his master and doctoral dissertations on the history of social physics: СПЕКТОРСКИЙ, Е. В. Проблема соииальной физики... 
also to offer the perfect ideal of morality. It is, however, feasible only in the "Kingdom of God" (i.e. off the ground), where, according to Lossky, not only spiritual but also physical life are subjects of conversion. ${ }^{15}$ Lossky is convinced that through the path of moral evolution people can elevate to such a state, therefore they can start a journey to deification.

Thus, a man is the first rational being on the Earth, who reached a certain level of sanity. At the same time, he is a limited creature (homo imbecillius) as manifestations of his weakness are bigger than manifestations of harmoniously developed moral force. Therefore, the way of life the man lives on the Earth is one of the possible ways to higher forms of life. The achievement of above-mentioned Kingdom of God, Kingdom of harmony and love becomes the ultimate ideal, the final goal, where an absolute perfection and creative implementation of absolute values are obtained.

Out of the mentioned it is evident that Lossky will solve all ethical problems based on the metaphysical assumption of the absolute perfect existence of the Kingdom of God, thus assumption which is anchored in the Christian religion.

In order to put forward his ethical concept he decided, in his main ethical work, which was published during his stay in Slovakia entitled Podmienky dokonalého dobra. Základy etiky [Condition of Absolute Good. Fundamentals of ethics] (1944), to issue in the footsteps of the most common ways in ethics, such as hedonism, eudemonism, biologism, naturalistic evolutionism, etc., to point out through a critical approach the advantages and the difference of his Christian ethical concept.

Concerning Spektorsky's philosophical position, it is necessary to emphasize that even though his intellectual life was rich and varied (as he changed methods and subjects of his investigation into various humanitarian fields), Spektorsky did not create his own original philosophical system. Characterizing his philosophical views, we must agree with its short resume by Spektorsky's colleague from Saint Volodymyr Royal University well-known religious philosopher Vladimir Zenkovsky:

From his primary admiration of German idealism Eugene Vasilievich quite early moved to philosophical relativism which he was inclined towards by his historical investigations. But here Eugene Vasilievich's philosophical examinations did not

15 LOSSKIJ, N. O. Podmienky dokonalého dobra... 
end-from relativism he moved implicitly to Christian idealism which grounded many his constructions. ${ }^{16}$

Actually, in the shortest possible way we can describe the evolution of Spektorsky's philosophical views as a movement from Neo-Kantian idealism to Christian idealism based on the New Testament.

Spektorsky's ethical-religious views are strongly connected to his philosophy of culture and anthropology presented mainly in his two works: Христианство и культура $[$ Christianity and Culture $](1925)^{17}$ and Христианская этика [The Christian Ethics] (lections given at Saint Vladimir's Orthodox Theological Academy in 1950-51 in New York).

For Spektorsky human most essential feature is an ability to overcome nature and create spiritual, social and material culture. This ability differentiates human from all other creatures and allows to define human as a "creature able to a cultural creativity" 18 . The notion of culture is closely connected to faith which makes human spiritual and free, able to rethink creatively and transform natural environment into cultural forms of science, philosophy, society and art. Furthermore, faith is always religious as it connects human with something supernatural and makes them overcome their own limitations and go outside empirical being. Inasmuch as faith always has a religious nature, our European culture requires Christianity as its ideology, where all the achievements are already grounded ("all our culture has grown from Christianity"19) and where it is possible to find moral ideals and values for nowadays and future.

At this point it is important to emphasize that Spektorsky understands Christianity first as a complete outlook and philosophical system. Using philosophical terminology, Spektorsky explains that Christianity is a transcendental idealism based on belief in ideal beings which are above our reality-God and Godman Jesus Christ who was sent to the Earth. The source of our knowledge about the foundations of reality is New Testament, "transcendental document of Christian consciousness", always present to some extend in culture.

Stated briefly, both Lossky and Spektorsky founded their ethics in Christian outlook and main Christian values, such as regarding God as ideal being

16 ЗЕНЬКОВСКИЙ, В. В. Е. В. Спекторский..., р. 317.

17 СПЕКТОРСКИЙ, Е. В. Христианство и культура...

18 Ibidem, p. 33.

19 СПЕКТОРСКИЙ, Е. В. Христианская этика.., р. 18. 
and unreachable aim for human existence, insisting on essential role of free will in choosing a path to God, accepting self-sacrificing love as central idea of ethics and main imperative for social behavior, and, finally, considering Christianity as the most perspective scenario for the future of humanity.

\section{The importance of human freedom in ethics}

When to follow Lossky's aforementioned methodical procedure of differentiating his ethical system from other trends right from the very beginning there emerges simple finding, which corresponds to Lossky's unequivocal statement that ethical theory that he defends "can be called Christian theonomic (God given) ethics of love" ${ }^{20}$. To point out ethics like theonomic means, according to Lossky, that the basic norms of this ethics correspond to the God's will and created order of the world. However, in the present context we come across the problem of interpretation of autonomy and heteronomy of ethics. Lossky does not admit, that such ethics would have heteronymous character. He considers it autonomous in that sense:

[I]ts norms, for example “... love your neighbour as yourself ", are binding not only because they are ruled by God, but also because their content is something valuable in itself, and therefore it deserves to be filled even from the point of view of beings that while wandering deny the existence of God. So it is clear that theonomic ethics consists of the valuable parts of autonomous ethics, avoiding the temptation of pride, hidden in the notion of autonomy as "self-legislation"; strictly speaking, there is no legislation, because moral norms are not created by my will, but they involve a vision of objective values of what it should be. While my freedom remains untouched: I can express norm, recognize its severity, and yet not to fulfil. ${ }^{21}$

We see an effort of Lossky to show that normative theonomic ethics is not inconsistent with the respect for the man's freedom and creativity, moreover, this argument allows him to accept a norm of absolute perfection ideal. Despite the fact that in earthly conditions, i.e. in the real world the norms are not possible to be fulfilled by any being,

20 LOSSKIJ, N. O. Podmienky dokonalého dobra..., p. 56.

21 Ibidem, p. 57. 
as soon as we recognize them, conscience gives the clear testimony in their favour and does not admit any reduction or decreasing of their content $[\ldots]$ although it would be seemed to us that they are unworkable. ${ }^{22}$

The same as for Lossky, for Spektorsky human way to God is not determined beforehand, it must be chosen freely without any enforcement. The importance of spiritual effort and creativity is essential for Spektorsky, because human is absolutely free to follow God or deny Him. Human freedom is not natural and proper to them but dependent on human activities, their choice and will, "it is not a physical, but a metaphysical freedom." ${ }^{23}$ Used in a right way, it is always a movement from physical world and nature to its overcoming in culture and metaphysics.

Despite the possibility not to live spiritual life, a true Christian should use their freedom in order to develop spiritually according to the example of Jesus Christ who is always present in human life as its only final goal:

[...] perfection means that human aims at creating inside the image and similarity of Godman, creating by their free will..$^{24}$

Although the ideal is unreachable, human must keep trying to reach it and put all their creative effort to get as close as possible.

As we can see, for both authors, humans are not determined in their choices, but in order to gain a self-realization and conscious life, human needs to believe in God and move in direction of His perfection and completeness, where the only truth could be found.

\section{Absolute basis of ethics and the way of its cognition}

Lossky's normative theory of love is also closely related to the interpretation of obligation. It turns out that the obligation is actually implicitly included and explicitly expressed in moral norms; therefore, to admit the obligation is also a challenge for man to create freely. This challenge once again refers to the existence of absolute moral ideal. Requirements of absolute ideal of

22 Ibidem, p. 58.

23 СПЕКТОРСКИЙ, Е. В. Христианство и культура..., р. 122.

24 Ibidem, p. 56. 
perfection are revealed to us by moral experience which incorporates the voice of conscience and - according to Lossky - is connected to an axiological experience.

The term of axiological experience, and regarding Scheler's emotional intuitivism, Lossky understands as "immediate perception of objective absolute values in conjunction with high emotions, intentionally directed to them." ${ }^{25}$ While he claims that the axiological and moral experience is accompanied by religious experience, "in which God is revealed as the highest value and the most dignified object of love" 26 , thereby he confronts various forms of ethical relativism, which refuses to recognize the absolute moral good as a measure of morality. He also considers that these three forms of human experience are enough for practical guidance on moral observance, but the theoretical elaboration of normative theonomic ethics of love requires other sources of cognition, such as philosophical speculation (intellectual intuition) and revelation. ${ }^{27}$

Lossky is even convinced, that neither objection from the side of existence of many different codes of morality cannot be the obstacle to the existence of absolute moral ideal of perfection, because different codes of morality are only the fractions of absolute perfection or the exchange of absolute ideal with incomplete ideal. They are just cognition of fragments of good and evil. ${ }^{28}$

We have seen that Lossky thus acknowledges the existence of different moral codes which can be observed in various historical periods, and also among certain populations or social groups that favor some values over the others and do not respect the overall ideal of perfection. Nevertheless, we can say that if their errors are only in their incompleteness and biases (i.e. in their partiality), so they correspond to the idea of normal (moral) evolution. It is unable to deny, however, that these partial codes of morality do involve the risk of disruption of relations between people.

Lossky accepts the existence of numerous codes of ethics, but he is an advocate of ethical absolutism in terms of the existence of the unity of morality, which "may provide the unity of action of all beings and a common system of values" ${ }^{29}$, and thus the possibility of absolute ethics development.

25 Ibidem, p. 59.

26 Ibidem, p. 59.

27 Ibidem, p. 59.

28 Ibidem, p. 79.

29 Ibidem, p. 83. 
To return to Spektorsky, he outlines two factors of human moral experience-subjective (inner) and objective (outer). The former is conscience or moral feeling and is common for all humans as moral beings. The latter could be called ethos and defined as a system of rules of behavior in society or laws in a state. Both are completely dependent on particular people or nationality, level of its development and its role in history.

Obviously, both Spektorsky and Lossky, who were deeply concerned with ethical issues in philosophy and culture, could not be satisfied with relativistic solutions. The latter is convinced that a foundation for ethics must be beyond time and space, "that is why ethics needs absolute foundation. It can be either nature or human or God." ${ }^{30}$ In history there are plenty of examples of grounding ethics in each of above-mentioned options, but later it was clarified that all of them are relative whereas only God is absolute ideal of perfection. Furthermore, Spektorsky claims that God is not united with the world in one, "God is outside the world. He is transcendent. And in the world, nobody has ever seen Him." ${ }^{11}$ Although this does not result in opposition as the world is connected to divinity via Godman and later via Holy Spirit co-present with people in a process of creative activity.

To summarize, both Lossky and Spektorsky do not accept any relativity in ethics. Although moral behavior of human is never perfect, and in history there are many examples of completely different ethical systems and cultural codes, the very foundation can be only one-God, cognized individually or in society, with intellect or in moral experience.

\section{Motives and goals of moral acting}

Although the validity of absolute ethics of love, which, according to both our authors, is the only way to achieve the Kingdom of God (Lossky) or "ideal state" (Spektorsky), is unquestionable, it is quite obvious that such ethics cannot be always realized or respected. In any case, it allows to evaluate human actions. Lossky's interpretation of human actions is also based on a distinction between the motives and the final goals of the action. These relate to values that are indicative for us, and therefore action (based on motives and goals) can be characterized as selfish (egoistic) or selfless (altruistic). When

30 СПЕКТОРСКИЙ, Е. В. Христианская этика.., р. 16.

31 СПЕКТОРСКИЙ, Е. В. Христианство и культура.., р. 89. 
it comes to "action whose final goal is personal satisfaction at the expense of other people's more valuable interests or at the expense of impersonal values such as truth, beauty, etc." 32 , it can be described as egoistic. Such a form of action may also be egoistic "an act aimed at personal life, whether it harms the realization of other values or not." 33

The opposite of egoistic action is selfless action, whose motive "is not one's separate life, but the embodiment of values such as truth, beauty, freedom and honor." ${ }^{34}$ Selfless (altruistic) action can manifest itself in heroic deeds as well as in everyday and quite ordinary situations.

Selfless action manifests itself very clearly in some cases of heroism, leading to the death of man, or at least the loss of one's position, a difficult struggle with the whole society. ${ }^{35}$

However, it is natural that in everyday life we come across it in much more humble or stealthy forms; for example, a mother who loves her children, a conscientious doctor, a teacher or educator who loves their profession and children. All of them are doing everyday actions that are obviously selfless. Finally, we can add that these actions are actually acts of love.

For Spektorsky, in fact, the notion of a goal and deontology in general is indispensable part of moral thinking. As far as human is free to choose their own path the category of oughtness is absolutely crucial for guiding them in different situations and spiritual formation. Moreover, according to Spektorsky, ethics is "deontology, issue regarding what is oughtness." 36 This oughtness is a starting point in ethical thinking, the next step in which is modality (questioning how what is ought to be may be implemented), and only that it switches to reality (to what extend moral ideals were realized according to available possibilities). ${ }^{37}$

Thus, the main ideal and central idea of Christian ethics according to Spektorsky is love. "Loves is above all the other goodness because it presents

32 LOSSKIJ, N. O. Podmienky dokonalého dobra.., p. 9.

33 Ibidem, p. 9

34 Ibidem, p. 10.

35 Ibidem, p. 9.

36 СПЕКТОРСКИЙ, Е. В. Христианство и культура..., р. 103.

37 СПЕКТОРСКИЙ, Е. В. Христианская этика..., р. 87. 
the whole of perfection." 38 As a result, all Christian ethical system is concentrated around the idea of love, "Christian ethics is an ethics of love." 39

As Spektorsky claims, Christian love is spiritual, so it is essential to distinguish it from corporeal love, empathy, affection or other emotional states; similarly, it is not erotic love, friendship or love in a marriage. On the contrary, it has two components: metaphysical (love to God) and social (love to other people). ${ }^{40}$ Metaphysical love can also be of two kinds-speculative or active when mind and intuition on one hand or will on the other are aimed at God. Social love in Spektorsky's version of Christian ethics is an ideal of self-sacrificing altruistic love not only to the nearest but to enemies who needs it even more.

It is brotherly love grounded on faith in Holy Father uniting us all and on longing for all-human perfection. ${ }^{41}$

Overall, Spektorsky's interpretation of love is very similar to altruistic acting in Lossky's doctrine. Both thinkers advocate ideal of self-sacrifizing and altruistic love, clearly distinguished from egoistic calculations or any other pragmatical motives. Thus, only this kind of love, articulated in Christian doctrine, could become a basis for moral actions and ethics.

\section{Moral evolution and future of humanity}

Looking at Lossky's and Spektorsky's reflections on the moral evolution of humanity, we find that both authors are convinced of the important role of Christian ethics in human history. They try not only to prove it factually but also to justify it theoretically. We have already shown that the assumptions of Lossky's ethics ${ }^{42}$ are given in his noetics and metaphysics. It is important to

38 СПЕКТОРСКИЙ, Е. В. Христианство и культура..., р. 130.

39 СПЕКТОРСКИЙ, Е. В. Христианская этика.., р. 87.

40 СПЕКТОРСКИЙ, Е. В. Христианство и культура.., р. 138.

41 Ibidem, p. 140.

42 Here we would like to add some more works by Lossky on ethical issues, e.g.: ЛОССКИЙ, Николай О. Свобода воли [Freedom of Will]. Paris: Ymca Press 1927; ЛОССКИЙ, Николай O. Teodícia Dostojevského [Dostoevsky's Theodicy]. Filozofický sbornik. 1942, 3(4), pp. 193209; ЛОССКИЙ, Николай О. Dostojevskij a jeho krestanský svetonáhl'ad [Dostoevsky and his Christian worldview]. Turčiansky sv. Martin: Tranoscius 1946. 
note at this point that, according to Lossky, man in his moral development wants to get as close to God as possible. But God's fullness cannot be attained in this world because, among other things, there is evil in man which he will never get rid of completely. But the fact that Lossky talks about moral development is interesting from a philosophical point of view. Lossky, as we have demonstrated, accepted the plurality of human morals, united by the fact that man had improved there, apart from the periods of regression or stagnation that have also occurred in history.

To a certain extent this reminds us of Hegel and his view on history of philosophy. For him each subsequent philosophy grows from the previous one by surpassing it (that is rejecting and also accepting something from it) and thus elevating it to a higher level. Without the previous one the next would not appear, so this is how the progress is moving forward. According to Hegel, the evolution of philosophy ends with himself as the speaker for the world spirit; his philosophy is the last and perfect one. Similarly, Lossky's point is that through the path of moral evolution people can improve themselves to a perfect state, so they can go on the path of worship, as we have already mentioned. However, the human history points out that the journey to the ideal state is no linear "progress", that there are winding roads, that in history we find both periods of decline and perfection. Thus, as Lossky notes, our time is a time of deterrent decline and it destroys belief in optimism.

We had to witness the constant formation of torture in cruel forms; in our times the hostage institute has reappeared; concentration camps were set up for hundreds of thousands of innocent people cruelly tortured there; there have been humiliating restrictions on the freedom of the press and all literary creativity, freedom of conscience, state interference in the family's life in order to raise a child in the spirit of quite absurd social ideals... ${ }^{43}$

However, Lossky urges man to "go up", showing him the path and goal of inner growth, which means approaching the fullness of being, the threshold of the Kingdom of God. This represents an ideal realm, a realm of harmony, love and perfection. Only in the Kingdom of God everything is infused with perfect love for themselves and for God, in the infinite perfection of spiritual life, freedom and individuality. And if all beings of the real world desire this

43 LOSSKIJ, N. O. Podmienky dokonalého dobra..., p. 255. 
perfection (albeit subconsciously), the only way to reach it is moral evolution which is guided by the moral ideal of perfection that can be chosen freely.

According to Spektorsky, moral evolution in human history was happening under the influence of church, philosophy, or apart from their protectorate it was being formed in social reality. Thus, from the end of Middle Age "morality of honesty", invented by merchants, was the most common among European peoples. Later bourgeois inherited its main principles which are professional competence and conscientiousness, fulfilling obligations in order to gain the most profit. This morality requires formal equality of people in terms of opportunities for work and earning money. The appearance of the proletariat broke the morality of honesty with the help of ideology created by Karl Marx who legitimized neglection of old order and old morality. ${ }^{44}$ Though nobody suggested any new one. A tendency to deny morals was accepted in logic of capitalism for which it does not play any role either as gaining new markets and making profit became its main values and goals.

Overall, having looked at the history of moral evolution, Spektorsky concludes its crisis and decline caused by immorality of proletariat, capital and state. Societies which found themselves in this situation he characterizes as "shapeless", "amorphous", "faceless", but malicious "democratic masses".

Spektorsky asserts that a reason for the crisis of morality in particular and culture in general is a situation when technical progress is much ahead of ethics and ideological (for Spektorsky always religious) part of life and cultural activity is ignored. In this case he objects arguments for weakness and defeat of Christianity:

It is not Christianity that did not succeed, but it is the attempt to create a wellbeing for human without Christ and even against Christ that did. ${ }^{45}$

Solution for this situation of crisis lays within understanding the very essence of culture and ways for its improvement-ways of Christian ethics, as the idea of spiritual evolution and development is immanent for Christianity. The ideals from New Testament are guides both for individual self-growth and the improvement for humanity.

44 СПЕКТОРСКИЙ, Е. В. Христианство и культура..., р. 146.

45 СПЕКТОРСКИЙ, Е. В. Христианская этика.., р. 148. 
All this evolution must be understood not as a fact, but as a task for spiritual and thus free human [...]. In free movement ahead [...] Christian evolution must take place, Christian movement towards perfection, Christian progress. ${ }^{46}$

Overall, both Lossky and Spectorsky understand history as an evolution, despite some periods of regress and stagnation. The way forward is not always obvious and straight, but it definitely moves towards God and His Kingdom as an ideal state of development of person in particular, and humanity in general.

\section{Conclusion}

To summarize, we may claim that, despite some difference in perspective, Lossky's and Spektorsky's views on the understanding of ethics demonstrate a high degree of affinity which, in our opinion, is based in their fundamental Christian (Orthodox) beliefs. While Lossky concentrates more on gnoseological issues and develops systematic and philosophical view (on the basis of his ideal-realism), Spektorsky gives more of the historical context and particular examples of the influence of Christianity on culture and ethics. Nevertheless, both ground their views in Christianity. As a result, for them hierarchy of being is clearly seen, and there is God on the top as an ideal for personal and social development. Despite impossibility to reach it, humans need to consciously improve their lives in order to come as close as possible to the ideal-with their creativity, altruistic moral acting and cognition of God. Only this way-towards Kingdom of God through moral evolution-can prove and realize real human nature and harmonic and peaceful future of humanity. The religious context of understanding their philosophical, ethical, cultural, and social issues is ubiquitous and does not seem to contradict their intellectual legacy in the field of ethics (or more broadly the evolution of human culture). However, we believe that there are certainly more parallels in intellectual legacy of these authors than we have mentioned in this article.

46 СПЕКТОРСКИЙ, Е. В. Христианство и культура.., р. 59. 


\section{References:}

ЛОССКИЙ, Николай О. Воспоминания. Жизнь и философский путь. München: Wilhelm Fink Verlag 1968.

ЛОССКИЙ, Николай О. История русской философии. Москва: Советский писатель 1991.

LOSSKIJ, Nikolaj O. Podmienky dokonalého dobra. Základy etiky [Condition of Absolute Good. Fundamentals of ethics]. Turčiansky sv. Martin: Matica slovenská 1944.

СПЕКТОРСКИЙ, Евгений В. Значение философии Н. О. Лосского. In Записки Русской академической группъ в США. Т. 10. Нью Йорк 1976.

СПЕКТОРСКИЙ, Евгений В. Проблема соииальной физики в XVII столетии: в 2 том. [The problem of social physics in 17th century: 2 vol.]. 2nd edition. СПб.: Наука 2006.

СПЕКТОРСКИЙ, Евгений В. Христианская этика: Лекиии, прочитанные в Свято-Владимирской Духовной академии в г. Нью-Йорке в 1950/51 академическом году. Сост., вступ. статья и примеч. БОЙКО, П. Е. - БОЙКО, Л. А. - Попов, И. В. Москва: Центр стратегической конъюнктуры 2013.

СПЕКТОРСКИЙ, Евгений В. Христианство и культура. 2-е изд., сост., вступ. статья и примеч. БОЙКО, П. Е. - БОЙКО, Л. А. Москва: Центр стратегической конъюнктуры 2013.

ЗЕНЬКОВСКИЙ, Владимир В. Е. В. Спекторский. In Русская религиозно-философская мысль XX века (Сборник статей под ред. Н. П. Полторацкого). Питтсбург: Отдел славянских языков и литератур Питтсбургского университета 1975.

\section{Prof. PhDr. Zlatica Plašienková, PhD.}

Department of Philosophy and History of Philosophy, Faculty of Arts, Comenius University in Bratislava

Gondova Street 2, 81499 Bratislava, Slovensko

zlatica.plasienkova@uniba.sk

\section{Mgr. Oksana Slobodian}

Department of Philosophy and Religious Studies, Yuchymenko Family Doctoral School, National University of Kyiv-Mohyla Academy

Skovorody Street 2, 04070 Kyiv, Ukraine

o.slobodyan@ukma.edu.ua

Toto dílo Ize užít v souladu s licenčními podmínkami Creative Commons BY-NC-ND 4.0 International (https://creativecommons.org/licenses/by-nc-nd/4.0/legalcode). Uvedené se nevztahuje na díla či prvky (např. obrazovou či fotografickou dokumentaci), které jsou v díle užity na základě smluvní licence nebo výjimky či omezení př́slušných práv. 
